\title{
Review on Impact of ICTs on Improving Agricultural Productivity and Rural Incomes in Ethiopia
}

\author{
Lelisa Daba Chibsa \\ Department of Rural Development and Agricultural Extension, College of Agriculture and Natural resource, \\ Madda Walabu University, P.O. Box 247, Robe, Ethiopia
}

\begin{abstract}
The experience in Ethiopia rapid development of Information and Communication Technologies, which facilitates the flow of data and information, has tremendously enhanced the knowledge management practice in agriculture. The objective of this paper is to review the impact of information and communication technologies to improve agricultural productivity and rural income in Ethiopian and review the recently developed agricultural knowledge and information systems in Ethiopia and others related documents. The study is based on a systematic review of existing literature of agricultural information communication and knowledge management system work in the country and supported documents of others countries. The review paper is organized in four sections. Section I focuses on importance of Information and Communication Technologies to the Ethiopian agricultural extension system. The second section discusses types of Information and Communication Technologies used by the farmers in Ethiopia. The third section to review the challenges and opportunities of Information and Communication Technologies ICT in provision of information services for the developments of agricultural production and generates rural income in Ethiopia. The findings of this study reveal that the various forms of Information and Communication technology have been used in agricultural service delivery and were more in tune with the circumstances and requirements of smallholder farmers. Therefore, the emergence of Information and Communication Technologies (ICT) in this era has opened new opportunities in agricultural knowledge management that could play an important role in meeting the prevailing challenges related to innovation, sharing, exchanging and disseminating agricultural information, knowledge and technologies to the intended smallholder farmers.
\end{abstract}

Keywords: Information communication technology; Agricultural Information; productivity; Rural Income; knowledge management system; Ethiopia

DOI: $10.7176 / \mathrm{IKM} / 10-5-01$

Publication date:August $31^{\text {st }} 2020$

\section{Introduction}

Information and Communication Technologies (ICTs) are any devices, tools that permit the exchange or collection of data through interaction or transmission. ICT is an umbrella term that includes radio, television, mobile phone, internet, electronic money transfer, etc., The ICTs increase productivity, access to markets and adaptability to weather conditions in agriculture. More effective interventions are needed in agriculture because rising food prices pushed over 40 million people in to poverty since 2010 (World Bank 2011). The growing global population which is expected to reach 9 billion by 2050, has heightened the demand for food and placed pressure on already- resources.

The strategic application of ICTs to the agricultural sector, which is the largest economic sector in most African countries, offers the best opportunity for economic growth and poverty alleviation on the continent (World Bank, AfDB and AUC 2012). Africa is the fastest growing region in the global telecommunications market. The number of mobile subscribers has further room for growth as Africa is being seen to have world's largest working-age population by 2040, which reflects the economic potential with a younger demography, of which $38 \%$ of the working youth in Africa are in the agricultural sector (UNECA 2012). Information and Communication Technology (ICT) increases connections, be it between small farmers and the larger traders who buy their produce, between multinational firms and the smaller manufacturers who build their parts, or between various firms and individuals around the world, linking rich and poor within and across countries. Depending on one's outlook, this should lead to more economic inclusion of emerging market countries, valuable job opportunities for lower income workers, and, overall, higher living standards for all (MGI [McKinsey Global Institute], 2013).

The importance of ICTs in development process was long recognized and access to ICTs was even made one of the targets of the Millennium Development Goal No. 8 (MDG 8), which emphasizes the benefits of new technologies, especially ICTs in the fight against poverty. The same report also observed "connectivity whether the Internet or mobile phones -- is increasingly bringing market information, financial services, and health services to remote areas, and is helping to change people's lives in unprecedented ways". ICT can play a crucial role in benefiting the resource- strapped farmers with up to date knowledge and information on agricultural technologies, best practices, markets, price trends, and weather conditions. Experts in public and 
private research and extension system could easily connect, collaborate and established working online and offline platform using the ICT tools.

The experience in Ethiopia rapid development of ICT, which facilitates the flow of data and information, has tremendously enhanced the knowledge management practice in agriculture. Thus, despite the fact that ICT has immense potential in disseminating agricultural knowledge and information, the low level of ICT infrastructure in Ethiopia is believed to have hindered the sector from realizing its potential. This has inhibited the effectiveness of FTCs in creating and delivering agricultural knowledge for use by rural farmers to increase productivity and production and to enhance efficiency. In most places, FTCs are not connected to modern ICT infrastructure and services. As a result, research-extension-farmer linkages are weak and costly; as such linkages have to be fostered through physical contact such as training, field demonstrations, field day programs and advisor. Thus, the main objective of this review paper is to review the importance of ICTs in the Provision of Information for Improving Agricultural Productivity and Rural Incomes in Ethiopia and review the recently developed agricultural knowledge systems in Ethiopia.

The specific objectives of this study are to:

1. To review the importance of ICTs for Agricultural Productivity and Rural Incomes

2. To review different type of ICTs used by the farmers.

3. To review the challenges and opportunities of ICT related information services for agricultural development

\section{LITERETURE REVIEW}

\subsection{ICT and development in Ethiopia}

One of the main reasons why ICT is not developed in Ethiopia is due to the fact that for decades, it has been considered a luxury by the general population and, most importantly, by high government officials, heads of private and government organizations, etc. It is therefore appropriate to clarify the role that ICT can play in solving the development problems of the country, before talking about policies for ICT development. Ethiopia, being one of the poorest countries of the world, faces a wide range of problems that it has to deal with in order to give its population an acceptable leaving condition. Some of the major problems are:

Poverty: Ethiopia has one of the lowest GNP per capita in the world (around US \$110). Most of its population lives in absolute poverty.

Illiteracy: Only $35 \%$ of its population is literate.

Poor education: A high percentage of its population does not get access to education. Successive governments claim that they have improved access to education for the citizens, but it is undeniable that the quality of education has dramatically fallen starting from the 1970s. The situation is so dramatic that today's average public high school graduate has acquired less knowledge in school than a primary school graduate some forty years ago, especially with regards to languages and general knowledge.

Poor health system: Public health facilities, which are the only health facilities that are still affordable by the majority of the population, can no longer cope with the alarming increase in the number of patients. Budget limitations and the scarcity of health professional are also some of the major problems. Brain drain in the health sector is becoming increasingly acute due to the very unattractive local working conditions, and high demand for health professional in developed countries.

Poor public service: the Ethiopian public service has become a major bottleneck for the whole economy. Today, it takes several years to process simple papers in government offices. For example, legalizing property transactions at the municipality is generally a painful activity that needs several days of queuing in front of overcrowded offices and that takes several years to complete.

Low industrial production: The country produces a small portion only of the industrial products it consumes. Its export of industrial products is virtually nil.

Inefficient agricultural production: Most of Ethiopia's population (more than $80 \%$ ) are farmers. Nevertheless, the country is not food self- sufficient due to inefficient agricultural methods and tools that the farmers use.

Bad governance: partly due to the inefficiency of the public service, citizens of Ethiopia are not getting the basic rights promised in the constitution. For example, due to the inefficient judiciary system, some falsely accused suspects stay in jail for years before their case is brought in front of a judge that sets them free.

As it can be seen above, the challenges of Ethiopia are immense and any sensible policy maker should use all opportunities that can help tackle the problems. The following benefits can be achieved in Ethiopia by implementing ICT:

Increased efficiency: A major cause of most socio-economic development problems indicated above arise from work inefficiency. Computerization can shorten this time several thousand times. Simple databases that can be accessed by all employees that need the data can dramatically improve the currently inefficient information system within government organizations. ICT can also improve the use of the scarce resources.

Increased knowledge acquisition and dissemination: Lack of knowledge is another major cause of the 
development problems. The problem in the education field comes mainly because the teachers themselves are not properly trained and they do not have the required means to improve their knowledge. Students have very little source to improve their knowledge. The agricultural and industrial sectors are suffering partly because the farmers and the industrialists don't get major knowledge that can help them improve their methods. ICT (ex: Internet) can help in bringing knowledge from the knowledge rich countries, but also disseminate the knowledge to the population.

Improved access to information: many of the problems of the public sector stem from the lack of adequate access to public information by the public at large. ICT can improve this situation by bringing up-to-date information to the public. For instance, in a country where Internet is widely used, any organization that wants to provide information to the public can achieve that goal by establishing a web site at minimum cost.

\subsection{ICT Devices that Support Agricultural Development}

Singh et al (2015) reported that Agriculture Information System (AIS) is a computer-based information system which contains all the interrelated information which could really help farmers in managing information and policy decision making. The ICT devices that help facilitating farming activities encompassed applications like radio, television, cellular phones, computers, tablets and networking, hardware and software, satellite systems (Munyua and Adera 2009; Pande and Deshmukh 2015). In the same way, (Yimer, 2015; Munyua and Adera 2009) reports that radio is extensively used to inform users on agricultural topics, including new and upgraded farming techniques, production management, and market information. This shows that farmers may take advantage of using radio in the absence of technology especially rural farmers.

The Internet and web-based applications are extensively used in sharing and dissemination of agricultural knowledge, marketing of goods and services. The study conducted by (Ramli et al, 2015) have shown evident that ICT is an effective solution to problems that militate against the development of agricultural industry, such as weak marketing linkages, poor information management, low productivity, low income and lack of diversity. Singh et al, (2015a) noted that the importance of ICT in agriculture by sharing agricultural information system to farmers at all level. But the major drawback of this research its references did not follow the format of the international standard.

\subsection{Conceptual Framework}

\subsubsection{Knowledge and information management in agricultural sector}

In the context of Ethiopia, generating new agricultural knowledge and information and making it available for use by smallholder farmers is important in promoting sustainable livelihoods and reducing rural poverty. Various entities are engaged in the creation and development of information and knowledge. Likewise, several repositories and intermediaries play their role to bring the information and knowledge to the ultimate users. Agricultural knowledge is created from modern and indigenous sources. The modern knowledge is created through scientific research (and therefore it is explicit knowledge) by universities and research institutes. Indigenous knowledge or tacit knowledge, on the other hand, refers to traditional knowledge, innovations and practices of local communities and is developed outside the formal education system.

Agricultural information and knowledge created from these sources is stored in various forms before it is disseminated for use. The main repositories of such knowledge include publications, audio visuals, and websites. The stored knowledge and information is then disseminated to users, such as rural farmers, through intermediaries notably during trainings, field visits, exhibitions, publications, and using traditional forms of ICT (TV and radio), modern forms of ICT (internet, mobile phone), and others. Figure 1shows the flow of agricultural knowledge and information from creation to end use 
Figure.1: Conceptual Framework of Knowledge \& Information management Systems

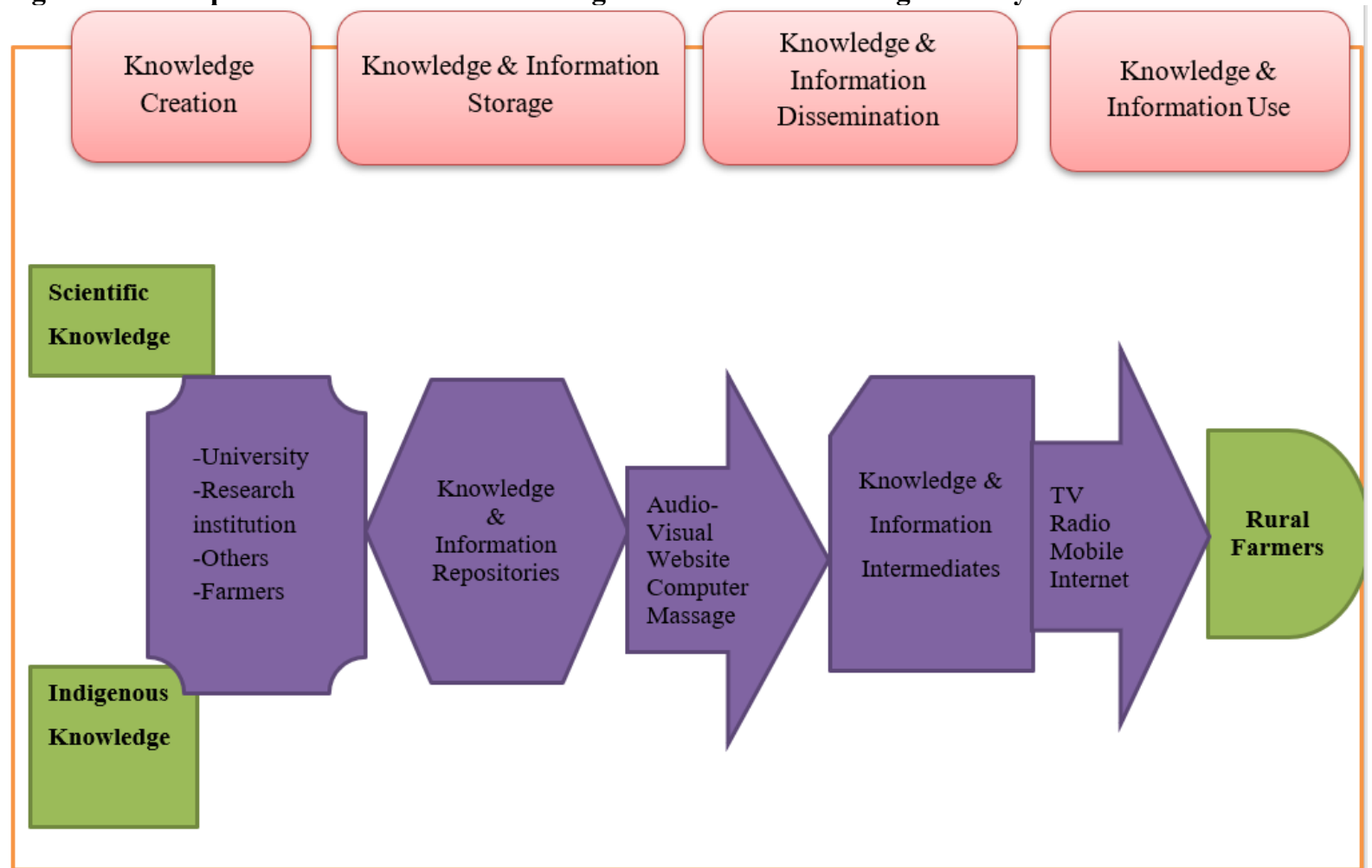

Effective knowledge management is achieved when the right knowledge and information is delivered to the right person at the right time in a user friendly and accessible manner that helps the recipients to perform their jobs efficiently (Islam 2010). The outcome of effective knowledge management includes improved productivity and performance of the agricultural sector. The attainment of effective knowledge management in the agriculture sector requires the systematic and continuous interaction of stakeholders that include farmers, farmer organizations, research scientists, policy makers, extension agents and the private sector among others (ASARECA, 2010).

Therefore, to be effective, knowledge management in agriculture must embrace the following four issues; (i) comprehensive of knowledge what needs to be done to solve to the sectors problems or exploit its potentials (ii) identifying how the problem can be solved or opportunities can be exploited (iii) the source of knowledge required for success; and (iv) determination of who would be responsible for taking the actions needed to solve the problem or exploit the identified opportunities.

\subsection{Empirical review}

\subsubsection{Importance of ICT on agricultural development}

Even though the history of broadcast media in Ethiopia is relatively old, its development has been so slow until the last decade, when the expansion of both governments owned and the private media have been noted. The electronic media, which is still under government ownership, has increased its airtime very recently and also its coverage of development issues has expanded. Radio stations, mainly FM stations, have tremendously increased and the installation of community radio stations is being considered by private and government institutions. These all in one way or another way deal with issues especially related to agricultural extension and rural development (Kirub, 2008).

ATA (2014) notes apart from scientists and researchers, the agriculture sector has a variety of players and stakeholders including farmers, commodity brokers, buyers, extension workers, policy makers and end consumers. Each of these stakeholders has varying needs for, and uses of ICTs, all within the common thread of knowledge and information brokerage and sharing. The most prevalent use of ICTs in agriculture is to provide farmers with information and advisory services. The Forum for Agricultural Research in Africa (FARA) has compiled a comprehensive inventory of initiatives providing such services (FARA, 2013). From the results of the inventory, the basic information needs for farmers are market information prices, weather forecasts, transport facilities, information on storage facilities and information related to crop and livestock diseases and general advice related to agriculture. ICTs are being used by Several Africa and Asia countries for the dissemination of agricultural knowledge and information and a number of success stories have been registered that can be exemplified and scaled up in Ethiopia (UNDP, 2012). Among other ICTs, mobile telephony has emerged as the 
technology of choice of the majority of the urban and even the rural masses (Ansari and Pandey, 2013). Using ICTs, the information is provided in a variety of ways: SMS, voice, web portal and call center. The inventory indicates that several of the information services have been developed in order to provide information in a standard way using question and answer services and that the most popular services are audio or voice based.

Chhachhar, et.al (2014) revealed that internet, mobile phones, radio and television were the most important tools of communication providing knowledge and information to farmers about agriculture. In remote areas radio was favorite tool of communication which broadcasts many agriculture programs while television also contributed much in disseminating information about agriculture in developing countries. Mobile phones reduced the gap among farmers and buyers. Farmers directly communicated with customers and got price of their products from market. Farmers got latest information from metrological department for weather conditions before using pesticides in their farms. Internet also disseminated information regarding price and marketing of goods and farmers received information within minutes from all over the world. Murty and Albino (2012) revealed that in the context of India and Ethiopia television played a most vital role as a medium of diffusion information about agriculture. The farmers could get easily information by watching the agriculture related programs on television.

The Broadcast Agency of Ethiopia regulates the broadcast media (radio and television). Similarly, telecommunication is regulated by the Ethiopian Telecommunications Agency. The regulatory activity serves to promote a broader communication of agricultural and rural development information and to provide affordable telephone (both fixed and mobile) and Internet services as well as non-IP services such as radio and television (ETC, 2014). Effective knowledge and information management in the agricultural sector were achieved with the right knowledge and information delivered to the farmers and other stakeholders at the right time in a userfriendly and accessible manner. Farmers were involved in the knowledge management process as knowledge generated in a participatory manner and have a greater likelihood of being accepted and acted upon the knowledge. This participatory approach was enabled the integration of traditional or tacit knowledge of farmers with the modern forms of knowledge, and further enhances the utilization of knowledge disseminated to smallholder farmers.

Globally, the lowest levels of farm productivity are in Sub-Saharan Africa. If smallholder farmers become better informed about their technical options for increasing yields, their productivity usually rises, leading to better working conditions on farms and higher food security (Ragasa \& Mazunda, 2018). Supporting analogue agricultural extension services (such as one-time farm visits) with digital tools (such as repeated text messages) can amplify the reach of extension officers exponentially (Aker, 2011), can make services more transparent (Cole \& Fernando 2012), and can give farmers greater agency and trust in accessing the types of input information they need most (Ragasa \& Mazunda, 2018). ICTs were used for enhancing both research findings among the stake-holders which ensured optimum coordination between research and extension for the welfare of farmers.

In Ghana, Nyarko, Hildebrandt, Romagnoli and Soldani (2013), conducting a randomized experiment with 1,000 smallholder farmers between 2011 and 2013, provided their treatment group with free access to Esoko, a private weekly SMS market information service for crop prices. Their preliminary results found a 7 per cent increase in earnings for SMS-recipient yam farmers, presumably due to better bargaining power. A later version of the study by the same authors, Hildebrand, Nyarko, Romagnoli and Soldani (2015), showed 8 to 9 per cent higher farm gate prices and thus substantial improvements in yam farmers' living standards.

\subsection{Types of ICT tools used by the farmers in Ethiopia}

ICT can play a crucial role in benefiting the resource-strapped farmers with up to date knowledge and information on agricultural technologies, best practices, markets, price trends, and weather conditions. The experiences of most countries indicate that rapid development of ICT, which facilitates the flow of data and information, has tremendously enhanced the knowledge management practice in agriculture.

However, in Ethiopia the use of ICT for the accumulation and dissemination of knowledge and information is still low. Currently, among the various ICT related initiatives, radio is widely used to share and inform users on agricultural issues, including new and upgraded farming techniques, production management, market information, and other issues. Due to its strategic importance in reaching the majority of the smallholders, attempts are being made to strengthen the delivery of knowledge and information through radio programs.

The initiative of Farm Radio International (FRI) is one best case in the use of ICT for agriculture. FRI, a Canadian based not-for-profit organization, started its operation in Ethiopia in June 2011. It operates in direct partnership with some local radio broadcasters where it supports them to build the necessary skills to develop content that responds to the needs of local small-scale farmers. In order to provide the radio broadcasters with news and resources that help meet the needs of small -scale farmers, FRI produces a weekly publication called Farm Radio Weekly that is delivered to e-mail inboxes every week with free subscription. FRI also prepares and collects agriculture related knowledge and information and produce radio script that is used by the partner broad 
casters.

Apart from such traditional ICT tools (i.e., radio and TV), the use of modern ICT (computer, internet, mobile telephony, etc) remains very low in the country. However, some activities that make use of ICT tools in agricultural knowledge and information management are underway and are worth mentioning.

Mobile phone: Over the past few years, mobile phone operators have developed a variety of mobile services and applications in developing countries. The most prominent of these is mobile money transfers (known as $\mathrm{m}$ money), a system whereby money can be transferred to different users via a mobile phone. M-money applications can facilitate the delivery of complementary services to farmers (such as access to credit or savings, or agriculture and health insurance), thereby helping to address some of the "missing markets" that can constrain technology adoption (Foster and Rosenzweig 2010).

The mobile revolution has challenged extension to align functions and services with appropriate ICT tools. Mobile phones can be used by farmers, members of the community and extension workers to connect and communicate. Donner (2009) shares a number of services that use mobile phones for interaction with rural farmers. Providing market information is the most frequently offered service. This aligns with cell phone $s$ limited ability to convey information (Donner, 2009). All of the projects also provide more options to connect to services. Before mobile technologies, connecting to rural farms and providing information was time-consuming and involved hours of travel. The information provided can give farmers a critical resource.

Simple mobile phones can be used as a means of collecting both farmer and agent-level data, thereby improving the accountability of extension services (Dillon 2011). Voice and SMS can be used to collect data on farmers ${ }^{\text {ee }}$ adoption, costs and yields on a more frequent basis, rather than waiting for annual agricultural surveys, when recall data on costs and production are often subject to measurement error.

Radio and TV: Any "ICT for development" strategy is driven by certain technological determinism: ICT-based community development initiatives are a case of technology transfer and usually the emphasis is on the potential of the technology, mainly computer networks, to provide information and communication opportunities to the rural poor. For decades, "traditional" forms of ICTs have been used in advisory service provision. Radio and TV programs regularly feature weather and agricultural information have become more prevalent in advisory service provision in developing countries, and rural tele-centers have provided information on price and quality (FARA, 2009; Goyal, 2010)

A project on Improving Productivity and Market Success (IPMS) of Ethiopian Farmers was implemented with the objective of assisting the Ministry of Agriculture to develop a knowledge management system. This IPMS project has developed web-based portal and also established knowledge centers. The Ethiopian Agriculture Portal aggregates information from diverse national and international sources. It contains technology, market related as well as extension packages for a wide range of crops, forest products, and livestock. In addition, it deploys agricultural research outputs drawn from national and international research institutes, and higher education institutions. In response to the unavailability or poor internet network in many rural areas, the project has also developed an offline version of the portal that provides access to most of the features of the online version.

In addition, woreda knowledge centers are established in each of the pilot learning woredas, where it operates. Each center is equipped with computers, a printer, a TV set, DVD player, and telephone line and access to internet connection among others. These centers provide the respective woreda extension personnel easier access to agricultural information and thus empower them to be better prepared to discharge their duties. At present the IPMS project only operates in the ten pilot learning woredas. Any attempt to scale up the activity to other woredas and FTCs has been hampered by lack of electricity, internet connection, computer skills, and budget among others

The Ethiopian Commodity Exchange (ECX) is yet another notable organization that has embarked on some modern types of ICT-based information management system. It carries out trading of the agricultural commodities on its trading floor located in Addis Ababa and disseminates price information in real time to producers, consumers, and traders using electronic price tickers as well as its website. At present, there are 30 price tickers installed in towns across the country and it is projected to reach 150 by the end of 2012. The price tickers are also used to transmit any change of price information directly in real time to the users.

In addition, ECX has developed a prototype for data dissemination using short message services (SMS) and interactive voice response (IVR). There are currently about 200 thousand users of the SMS service, and about 50 thousand IVR users per day of which, the majority (65 percent), are from outside Addis Ababa.

The use of ICTs to improve information flow and to connect people within the rural areas has proved that illiteracy of farming communities may no longer be an excuse to deny some form of extension system. Communication or the dissemination of information about agricultural extension and productions play a vital role in sustaining an effective agricultural extension service. Hence, Nwachukwu (2003 \& 2010) affirmed that agricultural communication is the effective transfer of agricultural technological innovation from technology developers to the technology utilizers. For agricultural information to be useful, the extension agents have to 
map out the information and communication needs of farmers within their agricultural and socio-economic systems and help key elements in that system to find information they need, when they need it, in accessible term and language, at prices that are realistic, at the given available resources and developmental objectives. With the growth of mobile phone coverage, many of these initiatives have moved away from "traditional" ICTs to mobile telephony, including voice, SMS and internet-based services.

\subsection{The challenges and opportunities for using ICT for agricultural development in Ethiopia}

Challenges: In developing countries accessing adequate and functional internet services and other ICT facilities are among the major concerns to farmers both in the rural and urban areas. According to Carvalho et. al (2011), eChoupal has brought 10 percent increase in farmers revenue, 5 to 25 percent by RML, and up to by 40 percent for Esoko. The question therefore is what are the challenges that deter the replication of these and other successes stories in Ethiopia? Furthermore, what opportunities exist that can be exploited to strengthen ICTbased knowledge and information dissemination for the agriculture sector in this country?

The challenges of access to ICT can be divided into two: (i) access to ICT infrastructure and (ii) access to ICT services. The access to ICT infrastructure in Ethiopia is still very low despite some noticeable improvements registered in recent years. According to the country diagnostic report of the World Bank issued in March 2010, the coverage of ICT in Ethiopia is one of the lowest in Africa. For instance, the coverage of GSM signal is about 10 percent of the population compared to the 48 percent benchmark for low income countries. Similarly, at the time of assessment, the Internet bandwidth benchmark for low income countries is about 20 times higher than that of Ethiopia.

The low level of access to ICT infrastructure is also believed to have slowed the sharing and exchange of knowledge and information generated from research centers at national and regional levels. Relatedly, electricity infrastructure coverage in the rural parts of the country remains low despite recent efforts to extend the electricity grid to rural areas through the rural electrification program. The low level of electricity coverage has in turn inhibited the expansion of ICT services to rural areas (UNDP, 2012).

In spite of being a necessary condition, access to ICT infrastructure by itself is not sufficient for the dissemination of knowledge and information to occur through it. Access to ICT infrastructure must be accompanied by access to ICT services. In this respect, the other challenge is how to make ICT services both affordable and available in venues or modes that are convenient to smallholder farmers.

Furthermore, affordability poses a great challenge to accessibility of ICT service, especially among subsistent farmers. Moreover, although the tariff for modern ICT services such as mobile phone, internet, and fixed lines in Ethiopia is one of the lowest in Africa, prices are not that low in purchasing power parity terms when one takes into account the low levels of household per-capita income (Adam, 2010). Singh et al. (2014) reported some existing issues to include inadequate accessibility of ICT services to rural farmers, lack of basic skills of using ICT facilities in agriculture, inability of government to deliver adequate ICT knowledge to farmers. On the other hand, a study by Agu (2013), specifically focuses on the problems faced by women in agriculture like access to land, access/weak extension services, access to credit, lack of supportive policies, access/no adoption of new agricultural technologies, and restricted access to training and education. These issues continue to persist because information that could help the farmers adjust and minimize their problems were either absent or not sufficient

Similarly, in 2015, Barakabitze et al. investigated the implementation of ICTs in Agricultural Research Institutes (ARIs) for the improvement of agricultural productivity in Tanzania. Results revealed that the use of agricultural journals is limited due to unreliability and poor connectivity of the internet, and regular power cuts. Findings also showed that the use of specialized ICT devices have not been adequately recognized in agricultural activities due to low investment of ICTs that can be used for teaching and learning modern production techniques in research institutes. Moreover, challenges hampering the use of ICTs in ARIs have been listed to include inadequate computers and the supporting technological infrastructure, and low coordination of agricultural stakeholders due to institutional diversity and department disintegration. These findings were supported by Singh et al. (2014).

Opportunities: Current researches establish possible benefits of ICT in the advancement of agricultural technology have been well documented. This is likely due to the fact that farmers are increasingly accepting new technological revolutions in farming system and thus paper presents several benefits of ICT in agricultural industry:

Ethiopia has some ICT related opportunities that can be utilized in the dissemination of agricultural knowledge and information to the users. Thus, the presence of such modern ICT initiatives can be considered to be a good opportunity to enhance the flow of agricultural knowledge and information in the country. It is also an important medium to expand and effectively provide a wide range of other extension services including health and nutrition extension services and conducting civic education programs (Sosena, 2016). In addition, more than half of the kebeles in the country were linked to the network by the time of the assessment by Adam (2010). 
Thus, the presence of such modern ICT initiatives can be considered to be a good opportunity to enhance the flow of agricultural knowledge and information in the country. It is also an important medium to expand and effectively provide a wide range of other extension services including health and nutrition extension services and conducting civic education programs.

Furthermore, radio transmission covers over 80 percent of the country and about half of the Ethiopian households own a radio. This makes radio programs one of the most cost-effective channels for conveying agricultural knowledge and information to the rural community. There is potential to strengthen the use radio to enhance research-extension-farmer linkages in Ethiopia. Similarly, different study conducted in developing countries indicates that, the application of ICT could harmonize data between suppliers and clients and also enhance decision making process. Moreover, it could facilitate the exchange of supply and demand information between farmers and entrepreneurs (Kale et al, 2015; Ramli et al., 2015; Singh et al, 2015). This is consistent with Pande and Deshmukh, (2015) who argued that ICT help in finalizing decision making at the right time, to discover best solutions, and efficient systems for water management and irrigation to harvest maximum yields. Thus, the review has demonstrated that ICT facilitate agricultural growth for economic sustainability in many ways. This may include agricultural research, improvement of market activities, exchange of relevant information, profit gain, networking agricultural sector globally, conducting research and strategizing economic growth for self-reliance and sustainability.

\section{Conclusion}

This paper reviews the contribution of Information and Communication Technology to the Ethiopian agricultural extension system. A review of literature on importance of ICT in provision of information services for improving agricultural production and rural income in Ethiopia during the last twenty year reveals that a range of tools have been used. It is only in recent years that attempts have been made to adopt Information and communication technology to agricultural extension service delivery. Farmers were given different sources of options in using Information and Communication Technology tools in collecting information on technologies appropriate to their specific farming needs and those within their local social, cultural, economic, and political environment. The government organizations have been playing a leading role in introducing and popularizing Information and Communication Technology systems to agricultural extension service delivery. In this respect, the role played by Information and Communication Technology in transforming Ethiopian agricultural system is consummate. The findings of this study reveal that the various forms of Information and Communication technology have been used in agricultural service delivery and rural income generation services were more in tune with the circumstances and requirements of smallholder farmers. The finding of different review results showed that the impact of ICTs on agricultural production and rural income was positive relation.

The effect of television on production per acre was higher than radio and mobile phones due to different programmes broadcasted on television about the weather conditions, seed, fertilizer use etc., through discussions with the experts and success stories of farmers. The results of this study confirmed the outcome of the study by Chavula (2014) that ICTs played important role in agricultural production but it did not confirm that telephone main lines contributed significantly to agricultural growth.

This study also confirmed the results of research by Chhachhar, et.al (2014) which revealed that television contributed much in disseminating information about agriculture. The farmers got information by watching the agriculture related programs on television. A minority of studies show no positive effects. The latter are sometimes cited in support of the critical literature, but on closer inspection, they mostly point to inconclusive results due to particular circumstances that would need tweaking before ICTs could have their expected positive impact.

\section{Recommendation}

The recommendation that emerged from the foregoing literature reviews were as follows.

- ICTs contribution in disseminating knowledge and information is vital so the government:

$\checkmark$ Should give a very good emphasis in developing the ICT sector and integrated agricultural information system on agro technologies and techniques, pricing and market information so that strategic information could be provided to farmers and other stakeholders at national, provincial and district levels

$\checkmark$ Should increase access to ICTs by reducing Value Added Tax so that the small scale farmers also could use them as well as to increase the Accessibility telecoms and power infrastructure in rural areas to use ICTs in agriculture.

- In order to benefit the rural people, extensionists are grappling with the question of how to harness ICTs to improve rural livelihoods in order to contribute towards better information exchange and access.

- There is need to intensify the use of radio and television programs and integrates new technologies as a means to reach extension workers and farmers. 
- Government

- The Government and NGOs should sensitize the farmers on the benefits of using ICTs and ICT education in the schools and colleges/universities should be made compulsory to address the shortage of ICT skills.

- With Public-Private Partnership (PPP) ICT infrastructure should be developed across the country to ensure access to ICT technologies.

- The existing communication tower infrastructures should be upgraded to ensure better cell phone and internet coverage. Fibre Optic Cable should be promoted to improve the quality of network connectivity.

- Lastly, since Mobile phone and Radio contributed for higher agricultural productivity in the country, the farmers should be provided televisions at affordable price by reducing VAT and Sales tax and more time should be allocated for broadcasting programmes on use of success stories.

\section{REFERENCE}

Achugbue et.al (2011). ICTs and Information Needs of Female Farmers in DeltaState,Nigeria.http://www.ccsenet.org/journal/index.php/jas/article/download/23216/162 21.pdf Accessed July 24, 2015.

Agu, M. N. (2013). Application of ICT in agricultural sector: Women's perspective. International Journal of Soft Computing and Engineering, 2(6), 58-60

Aker, J.C. (2010): Information from Markets near and Far: Mobile Phones and Agricultural Markets in Niger. American Economic Journal: Applied Economics, 2 (3), PP. 46-59.

Ansari, M.A. and Pandey, N. (2013) Assessing the potential and use of mobile phones in agriculture. Karnataka Journal of Agricultural Sciences, 26(3): 388-392.

ATA (2014a). Transforming Agriculture in Ethiopia. Annual Report. Addis Ababa, Ethiopia.

ATA (2014b). Fact Sheet on the 8028 hotline and IVR/SMS system. Accessed from www.ata.gov.et.

Barrios et. al (2011). Impact assessment of the e- AGRIKultura project: Philippines. In D. J. Grimshaw and S. Kala (Eds.),Strengthening Rural Livelihoods The impact of information and communication technologies in Asia (pp. 89-108). Practical Action Publishing Ltd

Barakabitze, al. et.(2015). New technologies for disseminating and communicating agriculture knowledge and information (AKI): Challenges for Agricultural Research Institutes (ARI) in Tanzania. The Electronic Journal of Information Systems in Developing Countries, 70

BMGF (2010). Accelerating Ethiopian Agriculture Development for Growth, Food Security, and Equity.

Carvalho, A., Klarsfeld, L., and Lepicard, F. 2011. Leveraging Information and Communication Technology for the Base of the Pyramid: Innovative business models in education, health, agriculture and financial services.1)281-288,\%202014.pdf.

Chaula Hopestone Kayiska (2014): The role of ICTs in Agricultural Production in Africa; Journal of Development and Agricultural Economics, Vol. 6 (7), pp. 279-289, July, 2014.

Chhachhar et. al (2014) Impact of ICTs in Agriculture Development. Journal of Basic Applied Scientific Research, 4(1):281-288.http://www.textroad.com/pdf/JBASR/J.\%20Basic.\%20Appl.\%20Sci.\%20Res.,\%20

Dillon, Brian. (2011). "Using mobile phones to collect panel data in developing countries.l Journal of International Development.

Fafchamps, M and Minten, B. (2011). Impact of SMS-Based Agricultural Information on Indian Farmers. Unpublished manuscript.

FARA. (2009). Inventory of Innovative Farmer Advisory Services using ICTs Forum for Agricultural Research in Africa

Foster,et. al. (2010). "Microeconomics of Technology Adoption.” Annual Review of Economics.2:395 424.

Goyal, A. (2010). Information, Direct Access to Farmers, and Rural Market Performance in Central India. American Economic Journal: Applied

Halewood, N.J; Surya, P. (2012): Mobilising the Agricultural Value Chain in 2012, Information and Communication for Development - Maximising Mobile, World Bank, Washington D.C.

Hildebrandt, et.al (2015). Price information, inter-village networks, and 'bargaining spillovers': Experimental evidence from Ghana (Working Paper). https://editorialexpress.com/cgibin/conference/download.cgi?db_name=CSAE2015\&paper_id=1059

Jemal Kuru. (2010). Access and Utilization of Agricultural Knowledge and Informa tion by Women dairy Farmers in Ada ${ }^{e e}$ a district, Oromia Regional State, Ethiopia. MSc. Thesis, Haramaya University, Haramaya, Ethiopia.

Kirub L (2008). Information and Communication Technologies in Ethiopia: Past, Present and Future Potential for Social and Economic Development. Professional Association Workshop, Addis Ababa, Ethiopia.

Lokanathan et. al ( 2011). Price transparency in agricultural produce markets: Sri Lanka. In D. J. Grimshaw and S. Kala (Eds.), Strengthening Rural Livelihoods. The impact of information and communication 
technologies in Asia (pp. 15-32). Practical Action Publishing Ltd

Lwoga E.T and Stilwell, C. (2011).Access and use of agricultural information and knowledge

Meera, et. al (2004): Information and Communication Technology in Agricultural Development: A Comparative Analysis of three projects for India: Agren. Net Work Paper (135), pp.1-14.

MGI (McKinsey Global Institute) (2013). Lions go digital: The Internet's transformative potential in Africa, New York, NY: Author. Retrieved from https://www.mckinsey.com/industries/high- tech/ourinsights/lions-go-digital-the-internets-transformative-potential-in-africa

Mtega, Wulystan P. (2012). Access to and usage of information among rural Communities: a cases study of Kilosa District Morogoro Region in Tanzania. Volume 7, No.1, the Canadian journal of Library an information Practice and Research.

Munyua, H. and Adera, E., 2009. Emerging ICTs and their potential in revitalzing small-scale agriculture. Agricultural information worldwide, 2(1), pp.3-9.

Murty and Albino (2012): Electronic Media in Rural Agricultural Business: A Promotional Injection. National Monthly Refereed Journal of Research in Science and Technology, Vol. 1 (11), pp. 63-68.

Nwachukwu, I. (2010). Communication for development: Concept, principles and practice. Proceedings of the southeast Zonal workshop on effective extension communication methods and techniques for agricultural staff/personnel from ADPs, LGAs, RBDAs, NARIs, Polytechniques and NGOs. Umuahia, Abia State. (pp.14-20).

Pande, N. and Deshmukh, P., 2015. ICT: A Path towards Rural Empowerment through Telecommunication, Egovernance, and E-Agriculture. IBMRD's Journal of Management \& Research, 4(2), pp.47-54.

Ramli, S.A., Samah, B.A., Hassan, M.S., Omar, S.Z., Bolong, J. and Shaffri, H.A.M., 2015. Potential Benefits of ICT for Youth Agro-based Entrepreneurs in Malaysia. Journal of Applied Sciences, 15(3), p.411.

Ragasa, C. \& Mazunda, J. (2018). The impact of agricultural extension services in the context of a heavily subsidized input system: The case of Malawi. World Development, 105, 25-47

Raj et. al. (2011). A crop nutrient management decision support system: India. In D. J. Grimshaw and S. Kala (Eds.), Strengthening Rural Livelihoods. The impact of information and communication technologies in Asia (pp. 33-52). Practical Action Publishing Ltd.

Rizvi, S. M. H. (2011). Lifelines: livelihood solutions through mobile technology in India. In D. J. Grimshaw and S. Kala (Eds.), Strengthening Rural Livelihoods. The impact of information and communication technologies in Asia(pp. 53-70). Practical Action Publishing Ltd

Singh, K. M., Kumar, A., \& Singh, R. K. P., (2015a). Role of Information and Communication Technologies in Indian Agriculture: An Overview. Available at SSRN 2570710.

Singh, V., Sankhwar, S. and Pandey, D., (2015b). The Role of Information Communication Technology (ICT) in Agriculture. Global Journal of Multidisciplinary Studies, 3(4)

Sosena Obesie (2016). The role of ICT in agricultural knowledge communication in ATA: The case of agricultural information service hotline (8028) or the IVR/SMS system.

Swanson BE, Rajalahti R (2010). Strengthening Agricultural Extension and Advisory Systems: Procedures for Assessing, Transforming, and Evaluating Extension Systems. Agriculture and Rural Development Discussion Paper 45. Washington, D.C: World Bank.

Syed et. Al. (2015): Impact of ICTs on Productivity in Kapiri Mposhi district of Central Province in Zambia: European Journal of Business, Economics and Accountancy Vol. 4, No. 5, 2016 ISSN 2056-6018

UN ECA (2012): Economic Report on Africa 2012: Unleashing Africa's Potential as a Pole for Global Growth, UNECA, Addis Ababa, Ethiopia

UNDP, (2012), Promoting ICT based agricultural knowledge management to increase production and productivity of smallholder farmers in Ethiopia

World Bank. (2009). Gender in Agriculture Sourcebook. Washington, D. C.: Author.

World Bank. (2011). ICT in Agriculture: Connecting Smallholders to Knowledge, Networks, and Institutions (p. 405). Washington, D. C.: Author.

World Bank, et, al. (2012): The Transformational Use of Information and Communication Technologies in Africa, on http://siteresources.worldbank.org

Yimer, M., (2015). The Role of ICT for Good Governance and Agricultural Development in Ethiopia: Local Evidence from Southern Ethiopia. International Journal of Political Science and Development, 3(1), pp.3039.

Yordy, Christopher. (2008). The Economics of Rural Radio in Africa: An Introductory Study into the Costs and Revenues. Africa Farm Radio Research Initiative.Farm Radio. Available-athttp://unpan1.un.org/intradoc/groups/public/documents/unpa n/unpan037356.pdf.Economics, 2(3):22-45. 